\title{
The Future of the Social Investment State: Politics, Policies, and Outcomes
}

\author{
Special issue edited by Marius R. Busemeyer, Caroline de la Porte, Julian L. \\ Garritzmann, and Emmanuele Pavolini
}

\section{INTRODUCTION}

Across the advanced democracies, policies related to the welfare state are the largest part of public policy activity. After a long period of expansion in the post-war decades, welfare states in advanced post-industrial democracies entered a new phase of consolidation and transformation in the 1980s. Policy-makers simultaneously faced multiple challenges. On the one hand, globalisation, rising public debts, and demographic changes have led to 'permanent austerity' (Pierson 2001), which has required welfare retrenchment and cost containment. On the other hand, 'new social risks' (Bonoli 2007; Esping-Andersen 1999) related to and emerging from precarious employment, labour market dualisation, youth unemployment, reconciling work and family life, and single-parenthood have generated new public demands for welfare expansion.

Many policy-makers and academics have argued that focusing on social investments (SIs) rather than passive social transfers could become a key strategy to deal with these crosspressures and to modernise European welfare states. Instead of, or in addition to, compensating citizens ex post for income- or job-losses as the 'old' welfare states have done, proponents of SI (Esping-Andersen 2002; Hemerijck 2013; Morel et al. 2012) have recommended the recalibration of social policy towards more future-oriented policies, centring on human capital development throughout the life-course. SI policies aim at 'creating, mobilizing, or preserving 
skills' (Garritzmann et al. 2017: 37). These investment policies - such as active labour market policies, public childcare provision, or education - are regarded by many as a 'magic bullet': Ideally, they could simultaneously empower individuals, facilitate the reconciliation of work and family life, and thereby contribute to economic growth and social cohesion (Morel et al. 2012). However, the effects of SI on poverty and on different forms of inequality are not so clear (Vandenbroucke and Vleminckx 2011; Cantillon 2011). That said, SI has a distinct agenda, which focuses on capabilities. It is not seen as a replacement for health care or pensions, to name two of the most costly social protection policies. However, investment in skills is integrated with many policies that have previously been associated with passive transfers, such as social assistance or labour market policy.

Research on the rise of the SI state has grown significantly in the 2000s. While its popularity has grown among policy-makers, academics, and the general public, the discussion about its effectiveness and legitimacy has become more intense (Hemerijck 2017). Most existing research has traced the transformation of welfare states towards SI, or the lack thereof (Bonoli 2013; Morel et al. 2012; Hemerijck 2013). The contributions to this collection of papers add new insights to this line of research, but also address two significant gaps in the literature: the politics of SI policies and the effects of SI policies on important outcomes. They study various kinds of SI policies (childcare, education, family, and labour market policies) using a wide variety of theoretical and methodological approaches. While contributing to ongoing debates, they also open up a number of new themes by focusing, for example, on the important but neglected group of migrants or by connecting the SI debate to research in demography, political behaviour, and political psychology. To foreshadow some of the key insights and cross-cutting themes, we have clustered the main findings around three central research questions. 
TRANSFORMATIONS TOWARDS SOCIAL INVESTMENT: INNOVATION IN A TIME OF PERMANENT AUSTERITY

How, and to what degree, is SI implemented in European welfare states and at the European Union (EU) level? Several contributions in this collection show that, even in times of 'permanent austerity' (Pierson 2001) and 'frozen landscapes' (Esping-Andersen 1996) for the welfare state, a significant number of countries have expanded SI policies. Furthermore, the SI approach has been prominent - at least rhetorically - at the EU level. Our collection's first essay, by Anton Hemerijck, sets the scene by providing background on the conceptual and historical development of the SI paradigm, complemented with country examples of transformations of European welfare states towards this model. Hemerijck shows that in some cases these transformations have been successful, but often go along with political 'uphill' battles against the proponents of the traditional welfare state model - that is, SI reforms in the advanced welfare states imply serious policy and fiscal trade-offs. The fact that politics is often 'impatient' (Ferrera 2016) can be a further hindrance to the introduction of SI policies, which - by design - often generate benefits more in the long-term.

The contribution by Caroline de la Porte and David Natali shows that SI has been a feature of the EU approach to welfare state reform over recent decades, even if only through soft law. The EU 'social investment moment' in the 2011-2013 period, when a comprehensive EU SI framework was delineated, emerged due to the role of three types of entrepreneur: intellectual, bureaucratic, and political. Despite this, there was little political support across EU institutions and member states for a strong EU SI, which explains why it was weakly institutionalized. The long-term time perspective in their analysis shows that the core aims of the European Employment Strategy and the social OMCs resurfaced with the EU SI. While scholars have 
highlighted that SI focuses on preparing rather than repairing, and on skills development, the EU SI frame is much broader. It also incorporates pre-existent EU initiatives around poverty and homelessness under the social inclusion OMC. The EU's 'social investment moment' has provided a broad narrative around EU social policy initiatives. This example, as well as the country examples from Hemerijck's contribution, reveal the ambiguity of SI. On the one hand, SI aims to provide skills across the life-course and therefore contrasts with the passive focus of more traditional welfare transfers. However, it can be used to propose SI as a replacement for social protection. Nevertheless, there is consensus among scholars that it should be seen as a complement to social protection (including pensions), and as a means to modernize the welfare state.

\section{THE POLITICS OF SOCIAL INVESTMENT}

Although SI policies have been studied for quite a while now, knowledge about the politics of SI remains limited (for a recent review, see Garritzmann et al. 2017). Several contributions in this volume seek to address this gap, studying which political actors foster (what kind of) SI policies, and whether the political dynamics of SI reforms are similar to those in the more traditional fields of welfare state policy-making. Are the politics of SI distinct from those of other social policies? To what degree are SI policies special?

Julian L. Garritzmann, Marius R. Busemeyer, and Erik Neimanns start with citizens' preferences and engage in a comparative analysis of public opinion towards SI and social compensation policies. The study of public opinion on SI has been a relatively neglected field due to limitations in publicly available survey data. Therefore, this paper employs novel data from a representative survey in eight European countries. Factor analyses reveal that people's 
social policy preferences cluster along three distinct dimensions: (1) traditional social compensation policies, such as unemployment benefits and pensions; (2) SI policies (active labour market policies [ALMPs] and education); and (3) 'workfare' policies (setting stronger incentives for the unemployed to take up work). The contribution thus shows that SI indeed is 'special', as the preferences towards SI and social compensation are distinct, leading to different political dynamics.

Complementing this analysis, the contribution by Silja Häusermann studies the politics of SI reforms exemplarily for the crucial case of family policies in Germany, pointing out their multidimensional character. Häusermann shows how the supporting coalitions of social compensation and SI policies differ (and change) in important ways, focusing on the political positions of collective actors such as parties, unions, and employers' associations. In Germany, new coalitions supporting progressive family policies have developed between the centre-left Social Democratic parties, centre-right Christian democrats, liberal politicians, and employers. This mirrors the micro-level findings in the study policy preferences by Garritzmann, Busemeyer, and Neimanns. They find that SI policies are supported the most by individuals with higher levels of education, who also subscribe to economically left-wing and/or to more egalitarian social values; in contrast, the coalitions supporting policy reforms expanding income protection and traditional forms of social compensation comprise (male) individuals with lower incomes and education levels. These differences highlight potential tensions in the electoral constituencies of mainstream left-wing parties: younger, left-libertarian individuals demand SI policies, whereas the traditional working class voters tend to be more in favour of income protection policies. 
In sum, there is strong evidence that the political dynamics of SI reforms indeed differ from those of traditional welfare state policies. This is a challenge, but also a chance for political parties seeking welfare reform, and offers interesting new dimensions regarding party competition and citizens' preferences and voting behaviour.

\section{SOCIAL INVESTMENT OUTCOMES: SOCIAL STRATIFICATION AND SOCIAL INEQUALITIES}

The third theme in this collection evaluates the consequences of SI policies for different kinds of inequalities. The starting point here is the notion that - compared to more traditional social policies, such as unemployment benefits or health care - the redistributive effects of SI policies are likely to be very different. A prominent criticism of SIs is that they are less effective in reducing poverty compared to traditional social policies (Cantillon 2011) as they are rather focused on the middle-class, particularly in corporatist-type welfare states. In this sense, SIs might in fact contribute to rising inequalities.

Two contributions in our collection study these 'Matthew effects' - that is, whether those that are already better off benefit the most from SI. Both contributions offer a more nuanced and differentiated look at the phenomenon. On the one hand, the magnitude of Matthew effects varies across policy fields: Matthew effects are stronger in childcare than in active labour market policies. Emmanuele Pavolini and Wim Van Lancker find that access to formal childcare is partially mediated by different social and cultural norms on motherhood. The likelihood of using formal childcare tends to be lower in countries with more traditional norms and, within countries, for those households that subscribe to more traditional views on motherhood. However, they find that Matthew effects are more the result of constraints on the 
'supply side' of formal child care by the state (policy design and insufficient levels of spending), rather than on the demand side (individual preferences and norms associated with usage patterns of formal childcare). This implies that a significant part of the (often criticized) 'Matthew effect' of SI can be attributed to how, and how much, states invest in and regulate social policies, although benefit recipients' preferences also play a significant role.

On the same theme, Giuliano Bonoli and Fabienne Liechti investigate ALMPs and provide evidence that Matthew effects are present only in some ALMP programmes, but not in others. In particular, Matthew effects have the strongest negative impact for programmes that require a given level of cognitive skills, such as training, and for those that are closest to the labour market, such as wage subsidies. In contrast, job creation programmes do not show particular signs of Matthew effects, at least for non-migrant, low-skilled workers. Again, this result is worrisome, because it indicates that particularly those ALMPs that have stronger SI elements produce more Matthew effects.

Both contributions show that the extent of Matthew effects also varies across countries. In general, in Scandinavian countries, where SI policies are well-established alongside compensation policies, the benefits of the former are more equally distributed across socioeconomic classes compared to Continental and Anglo-Saxon countries. Moreover, the contributions of this collection shed light on an emerging but crucial issue, which remains understudied in current research on SI - that is, to what extent can SI policies promote the inclusion of migrants? The contributions are a first step towards mitigating this research gap, revealing results that are worrying from a social inclusion perspective. For instance, Bonoli and Liechti underline that migrants are more exposed to Matthew effects in ALMPs compared to other disadvantaged social groups. As a result, they are more likely to be excluded from labour 
market programmes. Put differently, while SIs might decrease some inequalities, they also seem to create and reinforce new types of inequalities, such as those between migrants and nonmigrants. Going one step further, this implies that the more the advanced welfare states 'turn' towards SI, the bigger the inequality between native citizens and migrants might become.

\section{EXTENSIONS: NEW DIRECTIONS FOR RESEARCH ON SOCIAL INVESTMENT AND}

\section{BEYOND}

Finally, this collection contains two papers that open up new perspectives for research on SI policies. The first, by Paul Marx and Christopher Nguyen, connects welfare state research with literature on political behaviour. Marx and Nguyen analyse the extent to which SI policies contribute to political empowerment and participation at the micro-level. They find that SI indeed enhances political engagement among several socio-economically disadvantaged groups. More specifically, they demonstrate that in countries that invest significantly in SIs (education, childcare, and ALMPs), the 'political efficacy gap' is less pronounced for several risk groups than in other countries. That said, however, the contribution also shows that this increased efficacy does not translate into higher participation rates. More generally, Marx and Nguyen's contribution highlights the benefits of bringing together the SI literature with research on political behaviour and political psychology.

The second extension is the contribution by Róbert Gál, Pieter Vanhuysse, and Lili Vargha, which connects the SI debate with approaches in demography research. The paper represents an important expansion of the conventional perspective in public policy research, because it provides new data on the specific contribution of public policies relative to the broader contributions from individuals in society to well-being and redistribution efforts. The paper 
shows that many European welfare states are indeed characterized by a strong bias in public spending in favour of the elderly. The contribution presents new original data on monetary transfers, as well as time transfer across different types of welfare states. The findings suggest that the rather strong and well-known differences in welfare states in terms of redistribution become blurred when considering resources and time. Thus, as welfare societies, parents invest twice as many resources - both time and monetary - in their children compared to in older people. This suggests that policy-makers and academics should consider these investments when designing public policy and considering labour market policy.

\section{CONCLUSION}

Taken together, the contributions to this collection show that the notion of SI comes along with a high degree of ambiguity. This ambiguity relates to the concept of SI itself, its normative implications, and the empirical effects of SI policies on inequality. In politics, ambiguity can turn into a political asset, as different actors may use the notion of SI for different reasons (Jenson 2010; Morel et al. 2012). Several contributions in our volume find that policy actors exploit this ambiguity in the development of SI policies. De la Porte and Natali, in relation to the European Commission, as well as Häusermann, on the German case, show that SI policies have been introduced because the same policy can be supported by different actors, often for different reasons, resulting in heterogeneous coalitions promoting SI. For example, cross-class coalitions could form between the new educated middle class, represented by new left parties, liberal parties, skill-focused employers, and white-collar trade unions to promote SIs, whereas a coalition of old left and conservative parties, blue-collar unions, and low-skill firms could oppose these reforms, instead protecting the more traditional, compensatory welfare state. Hence, theoretical ambiguity has been useful in order to foster hybrid policy reforms, 
combining, for example, workfare policies with training subsidies and policies promoting the reconciliation of work and family life. In this sense, the politics of SI differ from those of more traditional compensatory redistributive social policies. Exploration of the link between ambiguity of SI and the political dynamics of reforms should receive further attention in future research. This is all the more true for non-Western democracies, where policy-makers have also begun to establish SI, but with different policy contents and politics, and at different points in time (Garritzmann et al. 2017).

Moreover, ambiguity also prevails when it comes to studying the effects of SI reforms on socioeconomic and political outcomes. On the one hand, some SI policies can, at least in theory, effectively promote the integration of labour market outsiders, the reduction of inequalities, and the universal provision of early childhood education to enhance equality of opportunities. On the other hand, there are concerns about Matthew effects and new kinds of inequalities emerging from SI, such as the exclusion of parents with traditional values from formal childcare and discrimination against migrants in active labour market policies. As is often the case, the institutional and political context matters. So far, we know that - as confirmed by the contributions in this collection - in universal-type welfare states where SIs and social compensation are used as complements, Matthew effects are less prevalent and the societies are more equal.

The future of the SI state is open. The current period can be regarded as a critical juncture for welfare state recalibration: On the one hand, SI is losing momentum at the supranational level and in many European countries, particularly against the background of right-wing (radical) populist parties gaining strength across Europe and favouring more traditional family structures and welfare state policies. In fact, right-wing populist parties might become the most important 
opposition to a 'social investment turn' in the near future. On the other hand, (new) political coalitions might (be able to) continue expanding SI. They also need to consider the quality of SI, which is crucial for it to be a success for those individuals towards whom SI is aimed. This seems economically and politically more viable in countries where SIs complement social compensation. Economically, more traditional social policies might be better able to mitigate poverty and economic inequality; however, SI seems better equipped to address the development of capabilities throughout the life-course. Politically, combining social compensation and SI is the most viable option, as it could be fostered by broader cross-class and intergenerational coalitions.

\section{References}

Bonoli, G. (2007) 'Time matters: postindustrialization, new social risks, and welfare state adaptation in advanced industrial democracies', Comparative Political Studies 40(5): $495-520$.

Cantillon, B. (2011) 'The paradox of the social investment state: Growth, employment and poverty in the Lisbon era', Journal of European Social Policy 21(5): 432-449.

Esping-Andersen, G. (1996) 'After the golden age? Welfare state dilemmas in a global economy', in G. Esping-Andersen (ed.) Welfare States in Transition: National Adaptations in Global Economies, London: Sage, pp. 1-33.

Esping-Andersen, G. (1999) Social Foundations of Postindustrial Economies, Oxford: Oxford University Press.

Esping-Andersen, G. (2002) Why we Need a New Welfare State, Oxford: Oxford University Press.

Ferrera, M. (2016) 'Impatient politics and social investment: The EU as 'policy facilitator', 
Journal of European Public Policy, 24(8): 1233-1251.

Garritzmann, J., Häusermann, S. Palier, B. and Zollinger, C. (2017) 'WOPSI: The World Politics of Social Investment', LIEPP Working Paper, no 64. Paris: SciencesPo.

Hemerijck, A. (2013) Changing Welfare States, Oxford: Oxford University Press.

Hemerijck, A. 2017) The Uses of Social Investment, Oxford: Oxford University Press.

Jenson, J. (2010) 'Diffusing Ideas for after Neoliberalism. The Social Investment Perspective in Europe and Latin America', Global Social Policy 10(1): 59-84.

Morel, N., Palier, B. and Palme, J. (2011) Towards a Social Investment State? Ideas, Policies and Challenges, Bristol: Policy Press.

Pierson, P. (2001) 'Coping with Permanent Austerity: Welfare State Restructuring in Affluent Democracies', in P. Pierson (Ed.), The New Politics of the Welfare State, Oxford: Oxford University Press, pp. 410-456.

Vandenbroucke, F. and Vleminckx, K. (2011) 'Disappointing poverty trends: Is the social investment state to blame?', Journal of European Social Policy 21(5): 450-471. 